\title{
Hunting and the conservation of a social ungulate: the white-lipped peccary Tayassu pecari in Calakmul, Mexico
}

\author{
Rafael Reyna-Hurtado, Eduardo Naranjo, Colin A. Chapman \\ and GEORGE W. TANNER
}

\begin{abstract}
The white-lipped peccary Tayassu pecari is a social ungulate that forms the largest groups documented for any tropical forest ungulate species. Since the 1950s the species has become increasingly rare in Mesoamerica, and the more frequent reporting of smaller groups may be related to increased hunting pressure. Here we address the conservation status of this species in terms of its group size and structure, breeding season, population density, and relationship with hunting patterns in the Calakmul region of southern Mexico. Group sizes, age structure and breeding season were recorded in one large non-hunted site (Calakmul Biosphere Reserve) and four adjacent hunted sites. Population density was estimated in the Reserve and hunting patterns were recorded from three adjacent villages. Results indicate that hunting pressure affects peccary populations by reducing group size. White-lipped peccary groups were larger in the Reserve $($ median $=25)$ than in the hunted areas $($ median $=16)$ but groups were generally smaller than those reported in other forests. These smaller group sizes indicate conservation concern for this species in the Calakmul region. In addition, the estimated population $\left(0.43 \mathrm{~km}^{2}\right)$ is one of the lowest reported for this species. Hunting occurs mainly in the dry season, which is the peak of the breeding season and when peccary groups visit water bodies, where they are more easily hunted.
\end{abstract}

Keywords Calakmul, density, group size, hunting, Mexico, Tayassu pecari, white-lipped peccary

\section{Introduction}

The white-lipped peccary Tayassu pecari, a Neotropical, L social ungulate, forms large groups of typically 20-300, although anecdotal sightings of $>1,000$ have been reported (Leopold, 1959; Emmons \& Feer, 1990; Alvarez del Toro, 1991; Bodmer et al., 1997; Sowls, 1997; Fragoso, 1998). This is

Rafael Reyna-Hurtado (Corresponding author) and Colin A. Chapman Department of Anthropology, McGill University, Montreal, Canada. E-mail rafael.reynahurtado@mail.mcgill.ca

Eduardo Naranjo Departamento de Ecología y Sistemática Terrestres, El Colegio de la Frontera Sur, San Cristóbal de Las Casas, Chiapas, México.

GeORge W. TANNER Department of Wildlife Ecology and Conservation, University of Florida, Gainesville, USA.

Received 28 January 2008. Revision requested 20 May 2008. Accepted 24 July 2008. an exceptional behaviour for an ungulate that lives in dense tropical forests (Caldecott et al., 1993). The white-lipped peccary is a mobile species that performs large-scale movements searching for food patches and water bodies. Recorded white-lipped peccary home range size is 18.7 (Keuroghlian et al., 2004) to $>200 \mathrm{~km}^{2}$ (Fragoso, 2004).

Since the 1950 s white-lipped peccaries have become increasingly rare in Mexico and Central America. They have disappeared from the Mexican states of Tabasco, Veracruz and Yucatan, and survive only in Oaxaca, Chiapas, Campeche and Quintana Roo (March, 1993; Taber et al., 2008). In areas where this species seems to be disappearing, herds of $<10$ are common (Emmons \& Feer, 1990). March (1993) suggested that frequent sighting of smaller groups is probably related to increased hunting pressure.

The Calakmul region in the state of Campeche is one of the few places where this species survives in Mexico. However, in the same area the white-lipped peccary is among the top five species preferred by subsistence hunters (Escamilla et al., 2000; Weber, 2000; Reyna-Hurtado, 2002). The relative abundance of this species was previously estimated in the Calakmul Biosphere Reserve and three community forests where hunting occurs, and found to be three times lower in hunted areas than in the protected area (Reyna-Hurtado \& Tanner, 2007). Additionally, legal sport hunting for this species is taking place under the UMA scheme (Units for Wildlife Management and Conservation; SEMARNAT, 1997). However, there is evidence that many UMAs are poorly administered, that population estimates are inaccurate, and that there is a lack of information regarding breeding season and other biological data that are essential for management of this species (Weber et al., 2006).

To provide information on the natural range of whitelipped peccary group sizes and to contribute to understanding the effects of hunting on group size, we quantified white-lipped peccary group sizes in the largest protected tropical forest in Mexico, the Calakmul Biosphere Reserve, where hunting and other human activities have been offcially prohibited since 1989 , and in three adjacent communal forests (ejidos) where subsistence hunting, as well as logging and other extractive activities, are currently taking place. A fourth hunted area (Calakmul-border), located between the reserve and one ejido, where hunting has been documented, was included. Additionally, we estimated white-lipped peccary density in the Reserve and collected 
information on reproductive season and age structure of white-lipped peccary groups in all areas. These data constitute the first report of white-lipped peccary group size, density, breeding season and age structure for the area, and one of the few for Mexico (Leopold, 1959; Alvarez del Toro, 1991; March, 1993; Naranjo, 2002).

\section{Study area}

The municipality of Calakmul is in the south-central part of the Yucatan Peninsula, in Campeche state, Mexico (Fig. 1). The climate is warm and sub-humid, with a mean annual temperature of $24.6^{\circ}$. Seasonal rain occurs mainly in summer and early autumn, with a mean annual total of 1,076 mm. A clearly defined humidity gradient increases from north-west to south-east. Calakmul is a mosaic of various forest types ranging from Medium Semi-Perennial Forest, with trees 15-25 m tall, to Low Flooded Forest, with trees 5-15 $\mathrm{m}$ tall (Pennington \& Sarukhán, 1998). Topography is flat and water resources derive from precipitation because there is no permanent river system. Most of the rainfall percolates through the limestone but some drains superficially into ponds, which are the only water source for wildlife in the dry season.

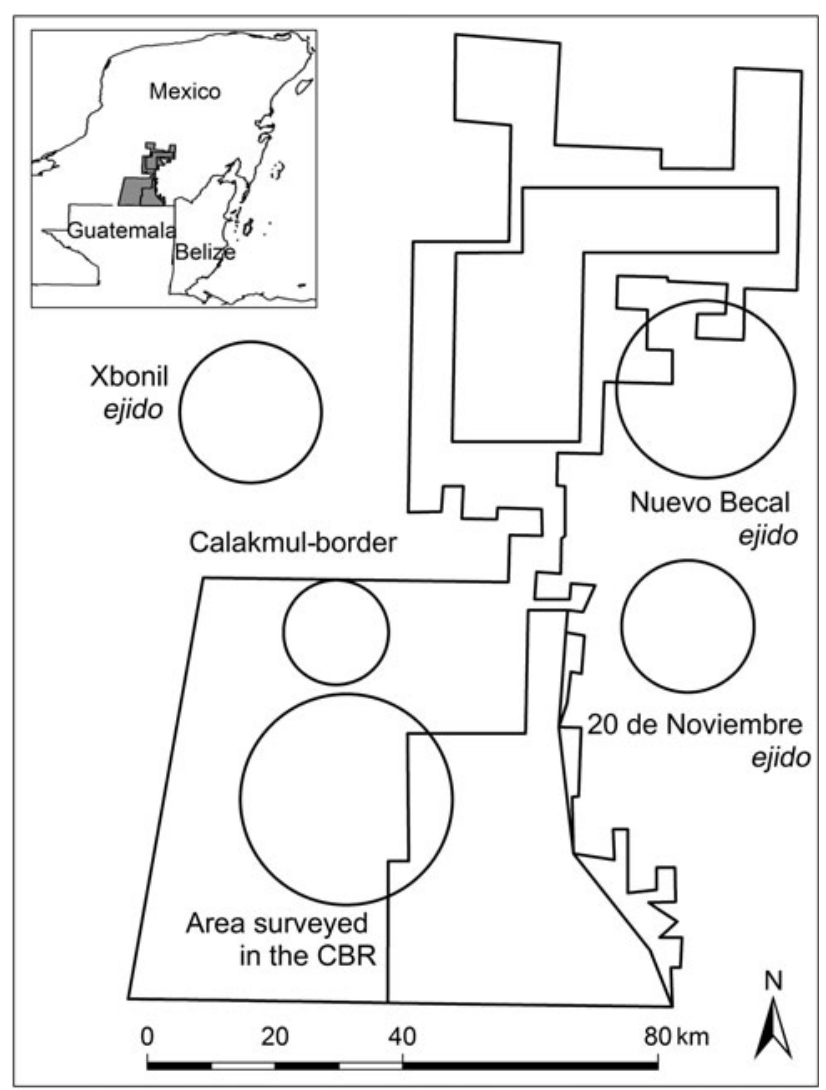

Fig. 1 The Calakmul region, Campeche, Mexico, with the five ovals indicating the areas surveyed in Calakmul Biosphere Reserve (CBR; shaded area on the inset), the three ejidos (communal forests), and the Calakmul-border area.
This region remained largely undisturbed after the Mayans abandoned it 1,100 years ago until government-encouraged colonization in the 1970s resulted in the establishment of 114 municipalities with 35,000 people within the Calakmul region and concomitant environmental changes (INEGI, 2005). In $19897,232 \mathrm{~km}^{2}$ of the forests in the region were decreed as the Calakmul Biosphere Reserve, which is the largest protected tropical forest in Mexico. Sport and subsistence hunting are now common activities along with other subsistence activities outside the Reserve (Weber, 2000; Escamilla et al., 2000; Reyna-Hurtado, 2002).

\section{Methods}

\section{Group sizes, age structure and breeding season}

Group sizes, age structure and the breeding season of the white-lipped peccary were recorded at five sites (Fig. 1): three communal forests (ejidos: Nuevo Becal, $520 \mathrm{~km}^{2} ; 20$ de Noviembre, $280 \mathrm{~km}^{2}$; Xbonil, $400 \mathrm{~km}^{2}$ ) where subsistence and sport hunting are common; a site that we refer to as Calakmul-border, which encompasses some ponds located at the border between the southern core of the Calakmul Biosphere Reserve and an ejido in which hunting occurs; and the southern core area of the Reserve (c. 3,500 $\mathrm{km}^{2}$ ). The latter site was at least $40 \mathrm{~km}$ south of the nearest human settlement and no hunting occurs there because of the isolation of the area and the fact that there are two check points along the only road accessing the area; during 18 months of fieldwork we did not detect any signs of human presence outside the areas visited by tourists.

Group size and age structure of white-lipped peccary groups were collected for each area. Age was based on body size categorized as: juvenile (from 1 day old to $50 \%$ of adult size), subadult (from $50 \%$ of adult size to slightly smaller than adults), and adults. We recorded reproductive season by noting the first time newborns were observed and, on a few occasions, by examining the developmental stage of foetuses from animals taken by hunters.

Data on group sizes were obtained from various sources. Firstly, we searched for groups of white-lipped peccaries in the Reserve and Calakmul-border with the assistance of two local resident hunters. Searches were in January-May 2001 and March 2005-August 2006 (Reyna-Hurtado et al., 2009). In the Reserve sightings were made by waiting for groups, from early morning to midday, to arrive at several water sources, especially during the dry season, and opportunistically in the main square of the archaeological site of Calakmul Old Mayan City.

We captured and radio-collared 17 individuals in four groups that were living sympatrically in the core area of the Reserve during 2005-2006, following a protocol previously established (IACUC permit no. D594; Reyna-Hurtado et al., 2009). We were able to differentiate groups by having 2-3 
individuals radio-collared in each group. After 18 months and c. 700 localizations we found that, in the Reserve, there was a spatial and temporal overlap of the groups' home ranges. Despite having large home ranges $\left(120 \mathrm{~km}^{2}\right.$, ReynaHurtado et al., 2009) these groups remained close to the centre of the Reserve and never travelled beyond it. We found groups to be cohesive, without exchange of individuals (Reyna-Hurtado et al., 2009). To reduce the possibility of counting the same group twice only sightings made at different locations were recorded. When several groups were seen at the same time and place only those that could clearly be differentiated (by observation or because they were radio-collared) were counted.

In addition to our field observations, information on group sizes was collected from hunters in the three ejidos (January-May 2001) and from observations made by our field assistants (during March 2005-August 2006) whilst performing their daily subsistence activities (e.g. farming corn and collecting honey). We only considered observations made by hunters and assistants in openings (e.g. ponds, forest clearings) or when, based on a structured interview, we concluded that the observer was confident of group size. Finally, one sighting of a group made in May 2000 by RR-H at one of the water sources in the Reserve was also included in the results, as well as an observation of a group made by a field assistant in 2007 at another pond in the Reserve.

\section{Density estimation}

We estimated white-lipped peccary density for the Reserve based on a minimum convex polygon constructed from locations obtained while searching the area intensively every month during March-December 2005 to make contact with the four radio-marked groups (named Red, Blue, Green and Yellow). We used this estimate because during these 10 months we had continuous contact with the four groups and precise counts of their group size. During this period we did not find signs of other groups. Every time we encountered a white-lipped peccary sign we were able to confirm the identity of the group using the radio-marked animals in each group. Group observations for $>200$ days confirmed high fidelity of marked individuals to their respective group (Reyna-Hurtado et al., 2009).

After this 10-month period we lost radio-contact with Yellow, and two groups (Green and Red) left the area and travelled to an unidentified area during the dry season of 2006. Therefore, we calculated a maximum density estimate by dividing the sum of individuals from the four groups over the whole area searched (encompassing the four groups' home ranges). Considering this estimate as a maximum density we extrapolated the density to the southern area of the Reserve, with the exception of a $5 \mathrm{~km}$ buffer at the border with the ejidos. This larger area has similar protection status and habitat types as the area occupied by the four monitored groups.

\section{Seasonality of hunting patterns}

Data on subsistence and sport hunting in the three ejidos were collected mainly by field assistants who lived there during 2005-2006 and by informal talks with subsistence hunters, who were visited every month from May 2005 to May 2006. We also included data that were collected in 2001 (Reyna-Hurtado, 2002) in systematic surveys that consisted of interviews of hunters from these three communities. Finally, we consulted the person in charge of the sport-hunting programme in Campeche (SEMARNAT, 1997).

\section{Statistical analyses}

A Mann-Whitney $U$ test was used to compare white-lipped peccary group size between non-hunted and the combined hunted areas (hunted and Calakmul-border). Comparison of group sizes between the three types of areas (non-hunted, hunted and Calakmul-border) was made with a Kruskal Wallis test. The proportion of individuals belonging to different age groups in hunted and non-hunted areas were tested with a contingency table and $\chi^{2}$ tests. Home range estimates were determined using the geographical information system ArcView v. 3.3 (ESRI, Redlands, USA) with the Animal Movement Analyst Extension (Hooge \& Eichenlaub, 1997; Reyna-Hurtado et al., 2009). All statistical analyses were performed with SPSS v. 11.5 (SPSS, Chicago, USA).

\section{Results}

Sizes of 24 white-lipped peccary groups were recorded in the four sites during 2000-2007 (Table 1). Ten observations were obtained from ejidos, nine from Calakmul Biosphere Reserve, and five from Calakmul-border. Considering Calakmul-border as a hunted site, groups were significantly larger in the non-hunted area (median $=25$, range $=19-35, \mathrm{n}=9$ ) than in the hunted areas (median $=16$, range $=11-35, \mathrm{n}=15$; Mann-Whitney test $\mathrm{P}=0.02, \mathrm{n}=24$ ). If the ejidos, Calakmul-border and the Reserve are compared separately, groups were significantly smaller in Calakmul-border (median $=15$, range $=11-16, \mathrm{n}=5$; Kruskal Wallis test $\mathrm{P}=0.01$, $\mathrm{df}=2$ ) than in the ejidos (median $=20$, range $=12-35$, $\mathrm{n}=10$ ) and in the Reserve. Group size in ejidos was not significantly different from in the Reserve (Mann-Whitney test $\mathrm{P}=0.18, \mathrm{n}=19$ ).

Age structure was recorded accurately for 21 whitelipped peccary groups (444 observed individuals). Adults comprised $90.3 \%$ (401) of the total, subadults $3.2 \%$ (14) and juveniles $6.5 \%$ (29). Eight of these groups contained only adults. In six groups we observed three age classes: $78.9 \%$ adults, $8.8 \%$ subadults and $12.3 \%$ juveniles. In six more we 
TABLE 1 Group size, group age composition, and date, place and source of observations of white-lipped peccaries Tayassu pecari observed in non-hunted areas in the Calakmul Biosphere Reserve (CBR), close to hunted areas, and hunted areas in the Calakmul region (Fig. 1), including the four radio-collared groups.

\begin{tabular}{|c|c|c|c|c|}
\hline Group size & Group composition ${ }^{\star}$ & Date & Place & Source \\
\hline \multicolumn{5}{|c|}{ Non-hunted areas } \\
\hline 30 & 25 ad., 5 juv. & 3 Apr. 2001 & $\begin{array}{l}\text { Pond near } \mathrm{km} 46 \\
\text { on road to Calakmul } \\
\text { Archaeological Site }\end{array}$ & $\begin{array}{l}\text { Biologist, students, } \\
\text { custodian }\end{array}$ \\
\hline 35 & 30 ad., 2 subad., 3 juv. & 25 Apr. 2001 & $\begin{array}{l}\text { Pond } 2 \mathrm{~km} \mathrm{~S} \text { of Calakmul } \\
\text { Archaeological Site }\end{array}$ & R. Reyna-Hurtado \\
\hline 26 & 26 ad. & 27 Apr. 2001 & $\begin{array}{l}\text { Pond near } \mathrm{km} 46 \text { on } \\
\text { road to Calakmul } \\
\text { Archaeological Site }\end{array}$ & R. Reyna-Hurtado \\
\hline 20 & 18 ad., 2 juv. & 3 May 2000 & Pond in heliport & R. Reyna-Hurtado \& others \\
\hline 31 & 28 ad., 2 subad., 1 juv. & 7 Mar. 2005 & Pond in heliport & R. Reyna-Hurtado \& others \\
\hline 25 & 20 ad., 3 subad., 2 juv. & 7 Mar. 2005 & Pond in heliport & R. Reyna-Hurtado \& others \\
\hline 25 & 20 ad., 2 subad., 3 juv. & 7 Mar. 2005 & Pond in heliport & R. Reyna-Hurtado \& others \\
\hline 20 & 18 ad., 2 juv. & 7 Mar. 2005 & Pond in heliport & R. Reyna-Hurtado \\
\hline 19 & $19 \mathrm{ad}$. & 18 Dec. 2005 & Pond in heliport & R. Reyna-Hurtado \\
\hline \multicolumn{5}{|c|}{ Close to hunted areas } \\
\hline 14 & 8 ad., 1 subad., 5 juv. & 28 Feb. 2001 & $\begin{array}{l}\text { Pond } 2 \mathrm{~km} \mathrm{E} \text { of checkpoint } \\
\text { at } \mathrm{km} 20 \text { on road to } \\
\text { Calakmul Archaeological } \\
\text { Site (Calakmul limit) }\end{array}$ & R. Reyna-Hurtado \& others \\
\hline 11 & 10 ad., 1 juv. & 14 Apr. 2001 & $\begin{array}{l}\text { Pond } 2 \mathrm{~km} \mathrm{E} \text { of checkpoint } \\
\text { at } \mathrm{km} 20 \text { on road to } \\
\text { Calakmul Archaeological } \\
\text { Site (Calakmul limit) }\end{array}$ & Field assistant \\
\hline 16 & 16 ad. & Apr. 2005 & Ramonal pond (Calakmul limit) & Biologist \\
\hline 15 & 12 ad., 2 subad., 1 juv. & Apr. 2006 & Oxpemul pond (Calakmul limit) & R. Reyna-Hurtado \\
\hline 15 & 14 ad., 1 juv. & Feb. 2007 & Oxpemul pond (Calakmul limit) & Field assistant \\
\hline \multicolumn{5}{|c|}{ Hunted areas } \\
\hline 25 & $25 \mathrm{ad}$. & Mar. 2001 & $\begin{array}{l}\text { El Verdin pond in } \\
\text { communal forest of } 20 \text { de } \\
\text { Noviembre ejido }\end{array}$ & Local hunter \\
\hline 12 & $12 \mathrm{ad}$. & 15 Apr. 2001 & $\begin{array}{l}\text { Los Muñecos pond in } \\
\text { communal forest of } \\
\text { Xbonil ejido }\end{array}$ & Local hunter \\
\hline 15 & $15 \mathrm{ad}$. & May 2001 & $\begin{array}{l}\text { El Güiro pond in communal } \\
\text { forest of Xbonil ejido }\end{array}$ & Field assistant \\
\hline 30 & 27 ad., 3 juv. & Oct. 2004 & Nosaya pond, Nuevo Becal ejido & Local \& sport hunters \\
\hline 13 & 11 ad., 2 subad. & 6 Apr. 2005 & $\begin{array}{l}\text { Chumakil pond in communal } \\
\text { forest of Nuevo Becal ejido }\end{array}$ & Field assistant \\
\hline 20 & $20 \mathrm{ad}$. & 15 Apr. 2005 & $\begin{array}{l}\text { Dos Guineas pond in } \\
\text { communal forest of Nuevo } \\
\text { Becal ejido }\end{array}$ & Field assistant \\
\hline 35 & Undetermined & Nov. 2005 & $\begin{array}{l}\text { Area known as Area Semillera, } \\
\text { Nuevo Becal ejido }\end{array}$ & Local hunter \\
\hline 20 & Undetermined & 26 Dec. 2005 & $\begin{array}{l}\text { Area of El Naranjalito, } \\
\text { Nuevo Becal ejido }\end{array}$ & Local hunter \\
\hline 27 & $27 \mathrm{ad}$. & Apr. 2006 & $\begin{array}{l}\text { Pond located } 400 \mathrm{~m} \text { to } \\
\mathrm{S} \text { of } \mathrm{km} 92 \text { of road } \\
\text { Escarcega-Chetumal, } \\
\text { Xbonil ejido }\end{array}$ & Local hunter \\
\hline 17 & Undetermined & 25 Apr. 2006 & $\begin{array}{l}\text { Aguada } 2 \text { Lagartos, Nuevo } \\
\text { Becal ejido }\end{array}$ & Field assistant \\
\hline
\end{tabular}

*ad., adult; juv., junvenile; subad., subadult (see text for definitions) 
observed only adults (89.4\%) and juveniles (10.6\%), and in just one group we observed adults (84.6\%) and subadults (15.4\%) without juveniles (Table 1). All groups with juveniles and newborns were sighted in the dry season (late December to early May) in both the hunted and nonhunted areas, with a single exception of a group with newborns in October. Although not statistically significant $\left(\chi^{2}=1.68, \mathrm{df}=1, \mathrm{P}=0.195\right)$ a larger proportion of groups with juveniles and subadults was sighted in the non-hunted (77\%) than in the hunted areas (50\%).

From 2001 to 2007 we recorded 19 births within at least 17 different groups from all study sites except from one of the ejidos (20 de Noviembre). In 18 cases births took place in the dry season between late December and March, with a peak of births in January-February (Fig. 2). On five occasions we observed females with pairs of newborns.

We recorded 21 hunting events in January-May 2001 and March 2005-August 2006; however, it is likely that some hunting events were undetected during these periods. The recorded hunting events were primarily by subsistence hunters (19) in the three ejidos and sport hunters (two) in one ejido. All but three of the hunting events took place during the dry season. The legal hunting season is from early April to mid May (Direccion General de Vida Silvestre, Campeche, pers. comm.). Of the 21 events, 17 were successful and hunters took 66 peccaries with a mean of three per event $(\mathrm{SE}=0.66, \mathrm{n}=21$, range $=0-13)$. Sport and subsistence hunters did not discriminate against females, or whether they were lactating or pregnant (R. ReynaHurtado, pers. obs.). In one example, combined subsistence and sport hunters harvested 27 white-lipped peccaries from a group of 29 individuals in only 2 months in 2005, leaving alive a single mother and her newborn (Weber et al., 2006). This event represented the almost complete elimination of one of three or four groups known from that ejido in the previous months (R. Reyna-Hurtado, unpubl. data).

For 10 months (March-December 2005) we had continuous radio contact with the four groups and searched

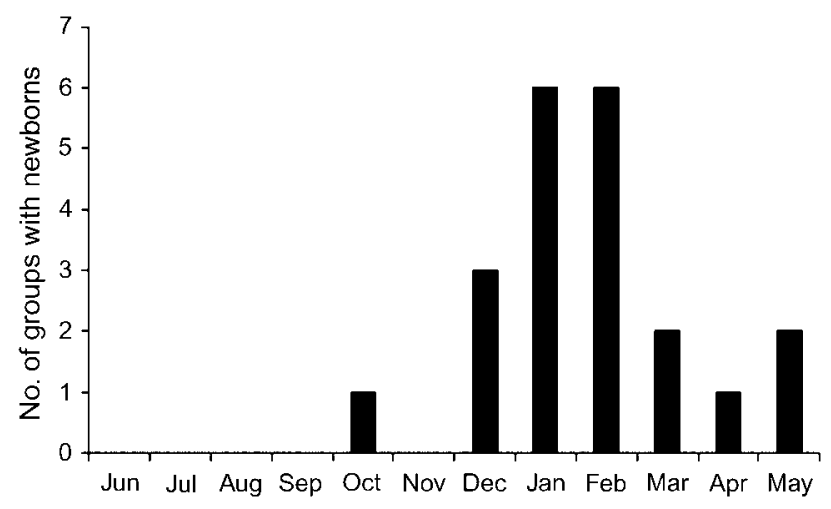

FIG. 2 Monthly frequency of births observed in groups of whitelipped peccaries Tayassu pecari in the Calakmul region (Fig. 1) during 2000-2007. intensively an area of $236.7 \mathrm{~km}^{2}$ (minimum convex polygon). During this time no other white-lipped peccary groups were detected in this area. The sizes of the four groups were $31,25,25$ and 20 at the beginning of the radiotelemetry study. The estimated density was one whitelipped peccary per $2.34 \mathrm{~km}^{2}$ (or $0.43 \mathrm{~km}^{-2}$ ). We used this density to estimate white-lipped peccary density for the whole southern area of the Reserve. This area comprises $3,509.41 \mathrm{~km}^{2}$ and has the same status of legal protection, similar level of isolation and similar proportions of forest types (according to analyses performed with ArcView $v 3.3$ using the classification made in 1995 by ECOSUR, G. Garcia-Gil, unpubl. data; Table 2). Assuming that whitelipped peccaries are uniformly distributed in this area and that the area sampled represents the whole of the southern part of the Reserve, we estimate a maximum number of 1,493 individuals. Considering that the median size of the nine groups recorded in the Reserve was 25 individuals, then a maximum of 60 groups is estimated to exist in the southern area of the Reserve.

\section{Discussion}

Groups of white-lipped peccary in Calakmul are smaller than those recorded in Peru, Brazil and Bolivia, where group sizes of $>100$ individuals are relatively common (Kiltie \& Terborgh, 1983; Peres, 1996; Sowls, 1997; Fragoso, 1998). However, group sizes in Calakmul are within the range reported for groups in a seasonally dry forest of Venezuela (14-60; Hernandez et al., 1995), in the dry forest of the Chaco in northern Argentina (7-50; Altrichter, 2005), in the humid forest of the Lacandon Forest in Chiapas, Mexico (5-60; Naranjo, 2002), and in the humid forest of Corcovado National Park in Costa Rica (16-70; Altrichter et al., 2002; Carrillo et al., 2002).

TABLE 2 Percentages of forest types and other habitats in the area used and shared by the four radio-collared groups (as determined from minimum convex polygons of their activity, see text for further details) and in the southern area of the Calakmul Biosphere Reserve (Fig. 1).

\begin{tabular}{|c|c|c|}
\hline Forest type & $\begin{array}{l}\text { Area used \& } \\
\text { shared by the } \\
\text { four groups (\%) }\end{array}$ & $\begin{array}{l}\text { Southern area } \\
\text { of Calakmul } \\
\text { Biosphere Reserve (\%) }\end{array}$ \\
\hline $\begin{array}{l}\text { Medium } \\
\text { semi-perennial } \\
\text { forest }\end{array}$ & 77.76 & 63.00 \\
\hline Low flooded forest & 14.14 & 19.31 \\
\hline Low dry forest & 08.00 & 13.8 \\
\hline $\begin{array}{l}\text { Ponds and other } \\
\text { water bodies }\end{array}$ & 00.07 & 00.04 \\
\hline Other & 00.00 & 03.80 \\
\hline Total area $\left(\mathrm{km}^{2}\right)$ & 236.66 & $3,509.41$ \\
\hline
\end{tabular}


It has been demonstrated that hunting is one of the main activities affecting the population size of white-lipped peccaries (Peres, 1996; Altrichter \& Boaglio, 2004; Naranjo \& Bodmer, 2007; Reyna-Hurtado \& Tanner, 2007). In the Calakmul region white-lipped peccary groups were larger in Calakmul Biosphere Reserve than in persistently hunted sites. Assuming that habitat types, habitat quality, humidity and weather are similar within the Calakmul region, and that groups in the Reserve are protected, the fact that whitelipped peccary groups in communal forests are smaller than in the Reserve suggests that the species is being affected by hunting. The cohesive behaviour of white-lipped peccary groups when facing danger (Peres, 1996; Sowls, 1997; N. Arias, pers. comm.) makes the group vulnerable to hunting because a hunter can kill several individuals at one time (Peres, 1996; Reyna-Hurtado, 2002; Weber et al., 2006). Furthermore, this species is highly prized by hunters in Calakmul (Weber, 2000; local hunters, pers. comm.); when a group is found, 2-3 day trips are organized to harvest as many peccaries as possible (Reyna-Hurtado, 2002). The results of our study suggest that hunting is reducing group size and, in some cases, eliminating complete groups. Additionally, in at least two ejidos (Nuevo Becal and 20 de Noviembre) groups are becoming isolated from the population in the Reserve. The effects of this increasing isolation on white-lipped peccary populations is uncertain but forest fragmentation could be an important cause of group size reduction given the requirement of this species for large areas (Sowls, 1997; Fragoso, 1998). This is especially true for the groups in Calakmul, which range over large areas $\left(>100 \mathrm{~km}^{2}\right)$, a home range size that is among the largest reported for this species (Reyna-Hurtado et al., 2009).

The proportion of non-adults in white-lipped peccary groups was similar to that reported for groups in the Lacandon Forest, Mexico (Naranjo \& Bodmer, 2007). Despite this, our observations of hunting patterns indicate that hunting could have a potential effect on age structure. We did not detect statistical differences in non-adult proportions between groups in hunted and non-hunted areas, although a lower number of groups with juveniles or subadults was observed in the hunted areas.

Data from this study indicate that breeding in Calakmul is during the dry season (January-May). This is surprising and warrants further research, given that the main period of fruit availability for peccaries starts in July when Brosimum alicastrum produces fruit in large quantities, in the middle of the rainy season. In addition, both young and adult whitelipped peccaries are most vulnerable to physiological stress and predation during the dry season, when they are attracted to the only remaining water sources (Reyna-Hurtado et al., 2009).

Hunting of white-lipped peccaries in Calakmul is primarily a dry season activity, when groups are easier to find at the few remaining water bodies. This situation may be particularly perilous for this population, where ponds can dry up following prolonged drought (Reyna-Hurtado et al., 2009), making the search for water a priority for white-lipped peccaries. In the dry season of 1997 a group approached a pond close to a village (Zoh Laguna village residents, pers. comms). During the dry season subsistence hunters can kill a large number of individuals, and sport hunters are allowed to hunt this species during the last 2 months of the season (AprilMay, SEMARNAT personnel, pers. comm.), probably a time of maximum physiological stress for white-lipped peccary groups.

Our estimate of density should be considered a maximum for the area, yet the white-lipped peccary population density in Calakmul Biosphere Reserve is among the lowest documented for the species. The only similar estimate is from the Argentine Chaco dry forest $\left(0.33 \mathrm{~km}^{-2}\right.$ for hunted sites and $1.04 \mathrm{~km}^{-2}$ for non-hunted sites; Altrichter, 2005). The Chaco dry forest and Calakmul are the driest areas in the species' range. Densities in more humid areas are higher. In the Lacandon Forest density varies from $1.08 \mathrm{~km}^{-2}$ in persistently hunted sites to $7.93 \mathrm{~km}^{-2}$ in slightly hunted sites (Naranjo \& Bodmer, 2007). In two fragmented sites in the Atlantic Forest of Brazil, density was 6.3 and $6.9 \mathrm{~km}^{-2}$ (Cullen, 1997; Keuroghlian et al., 2004). In the Peten Forest of northern Guatemala (which forms a continuous forest with Calakmul) a density of $9.6 \mathrm{~km}^{-2}$ was estimated for a non-hunted site (Novack et al., 2005). These differences could, however, be associated with the methods used or the higher rainfall that makes the taller and more humid Peten Forest more suitable for white-lipped peccaries than the drier forest of Calakmul. It is also possible, but untested, that the white-lipped peccary population in Calakmul may have cyclical changes in density that span for decades or that follow patterns of epidemic diseases, as has been suggested for the north-east Amazon (Fragoso, 2004). A more plausible explanation, however, for the low density is that Calakmul is at the edge of the species' distribution range and the habitat condition is sub-optimal for the species.

Recently, the white-lipped peccary density in the Calakmul region was estimated by wildlife technicians, using line transects, for developing sport harvest guidelines under the UMAs scheme (SEMARNAT, 1997). However, several flaws were detected in the estimation method, including non-systematic sampling and extrapolation of results to large areas (see Weber et al., 2006, for a more detailed description). These surveys may have overestimated whitelipped peccary populations. For example, in a $500 \mathrm{~km}^{2}$ ejido that lies just north of Calakmul Biosphere Reserve, the white-lipped peccary population was estimated at 1,3504,000 individuals (Direccion General de Vida SilvestreCampeche State, 2001). These numbers are in marked contrast to our maximum estimate of c. 1,500 for the whole 
southern area of Calakmul, which is seven times larger than this ejido. Overestimation could lead authorities to allow a high harvest rate, resulting in overhunting, especially when combined with subsistence hunting, an activity not regulated in the Calakmul region.

In 2008 the species' status on the IUCN Red List was changed from Least Concern to Near Threatened (IUCN, 2008) because of an apparent decline across its entire range (Taber et al., 2008), and a proposal to include the species on the national list of endangered species in Mexico (Norma Oficial Mexicana, NOM-059) has been submitted by RR-H and EN. Such a listing would legally ban sport hunting of the species in all UMAs. In the meantime, restrictions are required on the percentage of a group that any hunter can take. For example, if no hunter could legally take $>10 \%$ of any given group this would mean, considering that the median group size in the ejidos is 20 , that a maximum of only two individuals could be taken.

The government institution in charge of sport hunting (Direccion General de Vida Silvestre) and the NGOs involved in management and conservation of wildlife in Mexico need to consider and promote the development of conservation plans for white-lipped peccaries that involve subsistence hunters. Without the involvement and agreement of these hunters it is likely that white-lipped peccaries will soon disappear from the ejidos. Such a loss would have significant consequences for the remnant white-lipped peccary populations in the Calakmul Biosphere Reserve and for the ecological integrity of the forest.

\section{Acknowledgements}

We thank E. Rojas-Flores, N. Arias, G. Arias, E. Gutierrez and especially S. Perez-Cortez for invaluable help with fieldwork. F. Durand-Siller and C. Vidal provided research permits for the area. L. Branch, M. Christman, S. Calme, M. Altrichter and an anonymous reviewer read and improved the manuscript. M. Weber provided radio-telemetry equipment. This study was possible thanks to a CONACYTMexico grant 150332 to R. Reyna-Hurtado, to the Wildlife Conservation Society Research Fellowship Program, and IDEAWILD, who provided the funds for fieldwork and equipment.

\section{References}

Altrichter, M. (2005) The sustainability of subsistence hunting of peccaries in the Argentine Chaco. Biological Conservation, 126, 351-362.

Altrichter, M. \& Boaglio, G.I. (2004) Distribution and relative abundance of peccaries in the Argentine Chaco: associations with human factors. Biological Conservation, 116, 217-225.

Altrichter, M., Drews, C., Sáenz, J.C. \& Carrillo, E. (2002) Presupuesto de tiempo del Chancho Cariblanco (Tayassu pecari) en un bosque húmedo de Costa Rica. Biotropica, 34, 136-143.
Alvarez del Toro, M. (1991) Los mamíferos de Chiapas, 2nd edition. Gobierno del Estado, Tuxtla Gutiérrez, Mexico.

Bodmer, R., Aquino, R., Puertas, P., Reyes, C., Fang, T. \& Gottdenker, N. (1997) Manejo y uso sustentable de pecaries en la Amazonía Peruana. Occasional paper of the IUCN Species Survival Commission No. 18. IUCN-Sur, Quito, Ecuador.

Caldecott, J.O., Blouch, R.A. \& Macdonald, A. (1993) The bearded pig (Sus barbatus). In Pigs, Peccaries and Hippos (ed. W.L.R. Oliver), pp. 136-144. IUCN, Gland, Switzerland.

Carrillo, E., Saenz, J.C. \& Fuller, T.K. (2002) Movements and activities of white-lipped peccaries in Corcovado National Park, Costa Rica. Biological Conservation, 108, 317-324.

Cullen, L, JR. (1997) Hunting and biodiversity in Atlantic forest fragments, Brazil. MSc thesis, University of Florida, Gainesville, USA.

Direccion General de Vida Silvestre-Campeche State (2001) Estudio técnico de factibilidad de UMAS en la región de Calakmul. Campeche, Mexico.

Emmons, L.H. \& Feer, F. (1990) Neotropical Rainforest Mammals: A Field Guide. The University of Chicago Press, Chicago, USA.

Escamilla, A., Sanvicente, M., Sosa, M. \& Galindo-Leal, C. (2000) Habitat mosaic, wildlife availability, and hunting in the tropical forest of Calakmul, México. Conservation Biology, 14, 1592-1601.

Fragoso, J.M.V. (1998) Home range and movement patterns of white-lipped peccary (Tayassu pecari) herds in the northern Brazilian Amazon. Biotropica, 30, 458-469.

Fragoso, J.M.V. (2004) A long-term study of white-lipped peccary (Tayassu pecari) population fluctuation in northern Amazonia. In People in Nature: Wildlife Conservation in South and Central America (eds K. Silvius, R.E. Bodmer \& J.M.V. Fragoso), pp. 286296. Columbia University Press, New York, USA.

Hernandez, O.E., Barreto, G.R. \& Ojasti, J. (1995) Observations of behavioural patterns of white-lipped peccaries in the wild. Mammalia, 59, 146-148.

Hooge, P.N. \& Eichenlaub, B. (1997) Animal Movement Extension to ArcView, v. 1.1. Alaska Biological Science Center, US Geological Survey, Anchorage, USA.

INEGI (Instituto Nacional de Estadística Geografia e Informática) (2005) Conteo socio-económico del 2005. Estado de Campeche. INEGI, Campeche, Mexico.

IUCN (2008) 2008 IUCN Red List of Threatened Species. IUCN, Gland, Switzerland. Http://www.iucnredlist.org [accessed 21 August 2009].

Keuroghlian, A., Eaton, D.P. \& Longland, W.S. (2004) Area use by white-lipped and collared peccaries (Tayassu pecari and Tayassu tajacu) in a tropical forest fragment. Biological Conservation, 120, 411-425.

Kiltie, R.A. \& Terborgh, J. (1983) Observations on the behavior of rain forest peccaries in Perú: why do white-lipped peccaries form herds? Zeitschrift fur Tierpsychologie, 62, 241-255.

Leopold, A.S. (1959) Fauna Silvestre de México. Instituto Mexicano de Recursos Naturales Renovables, Mexico DF, Mexico.

MARCH, I.J. (1993) The white-lipped peccary (Tayassu pecari). In Pigs, Peccaries and Hippos (ed. W.L.R. Oliver), pp. 13-22. IUCN, Gland, Switzerland.

Naranjo, E.J. (2002) Population ecology and conservation of ungulates in the Lacandon forest, México. $\mathrm{PhD}$ thesis, University of Florida, Gainesville, USA.

NARANJo, E.J. \& BoDmer, R.E. (2007) Source-sink systems and conservation of hunted ungulates in the Lacandon Forest, Mexico. Biological Conservation, 138, 412-420.

Novack, A., Main, M., Sunquist, M. \& Labinsky, R. (2005) Foraging ecology of jaguar (Panthera onca) and puma (Puma 
concolor) in hunted and non-hunted sites within the Maya Biosphere Reserve, Guatemala. Journal of Zoology, 267, 167-178.

Pennington, T.D. \& Sarukhán, J. (1998) Árboles Tropicales de México. UNAM/Fondo de Cultura Económica, Mexico DF, Mexico.

Peres, C.A. (1996) Population status of white-lipped Tayassu pecari and collared peccaries T. tajacu in hunted and unhunted Amazonian forest. Biological Conservation, 77, 115-123.

Reyna-Hurtado, R. (2002) Hunting effects on the ungulate species in Calakmul Forest, Mexico. MSc thesis, University of Florida, Gainesville, USA.

Reyna-Hurtado, R., Rojas-Flores, E. \& Tanner, G.W. (2009) Home range and habitat preferences of white-lipped peccary groups (Tayassu pecari) in a seasonally tropical forest of the Yucatan Peninsula, Mexico. Journal of Mammalogy, in press.

Reyna-Hurtado, R. \& Tanner, G.W. (2007) Ungulate relative abundance in hunted and non-hunted sites in Calakmul Forest (Southern Mexico). Biodiversity and Conservation, 16, 743-757.

SEMARNAT (Secretaria del Medio Ambiente y Recursos Naturales) (1997) Programa de conservación de vida silvestre y diversificación productiva del sector rural 1997-2000. SEMARNAT, Mexico DF, Mexico.

Sow LS, L.K. (1997) Javelinas and the other Peccaries: Their Biology, Management and Use, 2nd edition. Texas A\&M University Press, College Station, USA.

Taber, A., Chalukian, S.C., Altrichter, M., Minkowski, K., Lizárraga, L., Sanderson, E. et al. (2008) Análisis de la Distribución y el Estado de Conservación del Tapir (Tapirus terrestris) y el Pecarí Labiado (Tayassu pecari) en Latinoamérica y una Llamada de Acción. IUCN Pigs, Peccaries and Hippos Specialist Group, IUCN Tapir Specialist Group, Wildlife Conservation Society, and Wildlife Trust, New York, USA.

WEBER, M. (2000) Effects of hunting on tropical deer populations in south-eastern Mexico. MSc thesis, Royal Veterinary College, University of London, London, UK.

Weber, M., García-Marmolejo, G. \& Reyna-Hurtado, R. (2006) The tragedy of the commons Mexican style: a critique of the Mexican UMAs concept as applied to wildlife management and use in south-eastern Mexico. Wildlife Society Bulletin, 34, $1480-1488$.

\section{Biographical sketches}

Rafael Reyna-Hurtado has studied the ecology and conservation of mammals in the Calakmul region for 10 years and is interested in the movement and behavioural ecology of threatened species of primates and ungulates. EdUARDo NARANJO is conducting studies on tropical ungulates and human impacts on their populations in the Lacandon forest in southern Mexico. Colin Chapman has conducted socio-ecological studies on primates for more than 29 years, with a focus on conservation; his main study site is Kibale National Park in Uganda. George W. Tanner has studied habitat management and conservation of native ungulates in Florida, USA, for more than 25 years. 